\title{
Izrael wobec zakazu sprzymierzania się z poganami w wybranych tekstach Septuaginty: część I
}

\section{Wstęp}

Proponowany artykuł stanowi pierwszy z trzech fragmentów szerszej analizy problemu zawierania przymierzy przez Izraelitów w różnych okresach historii narodu wybranego. Kwestia ta pojawia się zarówno w Pięcioksięgu, gdy chodzi o zapisy mojżeszowe, jak i w kolejnych księgach historycznych Starego Testamentu oraz w literaturze prorockiej. Badana problematyka w księgach natchnionych może o tyle zaciekawić, że w wielu istniejących komentarzach egzegetycznych ${ }^{2}$ brakuje jasnej odpowiedzi na pytanie o rozpiętość zakazu zawierania przymierzy z poganami, widniejącego $\mathrm{w}$ czterech podstawowych $\mathrm{w}$ tej tematyce wersetach starotestamentowych: Wj 23,32; 34,12; Pwt 7,2 oraz — dodatkowo Sdz 2,2. Autor pragnie wpierw udzielić pełniejszej odpowiedzi na pytanie: czy zakaz ów dotyczył wyłącznie narodów sąsiadujących z Izraelitami już po zajęciu przez naród wybrany ziemi obiecanej, czy również narodów pogańskich, któ-

${ }^{1}$ Ksiądz prof. dr hab. Janusz Nawrot — ur. w 1960 roku w Międzychodzie, woj. wielkopolskie; kapłan archidiecezji poznańskiej od 1985 roku; wykładowca WT UAM w Poznaniu; kierownik Zakładu Nauk Biblijnych; specjalizuje się w egzegezie i teologii Starego Testamentu; jannaw@ amu.edu.pl; ORCID: 0000-0002-2498-5081.

${ }^{2}$ Najnowszy, polski komentarz J. Lemańskiego do Księgi Wyjścia również nie porusza wnikliwiej tej kwestii, sugerując jedynie, że chodzi raczej o „rdzennych mieszkańców ziemi” lub „rdzenną ludność Kanaanu", por. tenże, Księga Wyjścia, Wstęp - przekład z oryginału — komentarz, NKB.ST, t. II, Częstochowa 2009, s. 511, 640. Passus Wj 34,11-26 wymieniony został szkicowo w artykule J. Kułaczkowskiego, Specyfika wybranych zbiorów prawa w Pięcioksięgu, SKK 10 (2005), s. 145-155. W oczekiwaniu na polski komentarz do księgi Powtórzonego Prawa w ramach Nowego Komentarza Biblijnego bardzo ogólnie perykopę Pwt 7,1-6 poruszył jak dotąd tylko Z. Małecki w artykule Izrael i Kościól świętym ludem Jahwe [w:] Vobis Episcopus Vobiscum Christianus. Księga Jubileuszowa dedykowana Księdzu Arcybiskupowi Damianowi Zimoniowi w dwudziestolecie posługi biskupiej $w$ archidiecezji katowickiej oraz $w$ siedemdziesiąta rocznicę urodzin, red. W. Myszor, A. Malina, Katowice 2004, s. 218-230. 
re z nim graniczyły lub nie. Czy zatem pojmować ów zakaz restrykcyjnie, czy rozszerzająco? Ponadto zdefiniować trzeba istotę zakazu, tzn. czego on właściwie dotyczył: czy wszelkiej możliwości paktowania z poganami, czy tylko sfery czystości wiary, by nie narażać się na pokusę bałwochwalstwa? Część druga, już w osobnym omówieniu, podejmie kwestię wcale nie tak rzadkich przypadków zawierania przymierza przez samego Abrahama, później zaś różnych władców zjednoczonego, potem już rozbitego królestwa Izraela i Judy. Postawione zostanie wówczas pytanie o zgodność podejmowanych działań z owym zakazem, wyrażonym przez Mojżesza. Odpowiedź na powyższe kwestie stanie się na koniec punktem wyjścia w rozważaniach nad biblijną oceną hagiografa ewentualnej odpowiedzialności przywódców powstania machabejskiego wobec zakazu zawartego w wyżej wymienionych tekstach. Wszyscy oni zawarli bowiem przymierze z republiką rzymską, będącą skądinąd krajem pogańskim. Czy zatem popełnili wykroczenie przeciw prawu Mojżeszowemu? Stanie się to tematem badań w trzeciej części proponowanej całości. By odpowiedzieć na powyższe pytania, należy obecnie podjąć próbę analizy teologicznego sensu zapisów autorów biblijnych w Pięcioksięgu.

Na samym początku trzeba jednak wyjaśnić, dlaczego autor pragnie oprzeć się na tekstach Septuaginty, nie zaś na źródłowych wersetach hebrajskich. Otóż wpierw dlatego, że tekst Pierwszej Księgi Machabejskiej, przytoczony w niniejszym opracowaniu, został napisany wyłącznie po grecku³. Stąd wydaje się naturalne, że bliższa mu będzie teologia Biblii greckiej niż hebrajskiej. Poza tym, mając na względzie kontynuację w osobnym omówieniu zaproponowanej tematyki w tej właśnie księdze, w sposób uzasadniony teologiczną łączność nawiąże się z greckim tekstem Starego Testamentu, do którego z pewnością odwoływał się hagiograf. Nie można bowiem dziś ustalić koneksji zaginionego oryginału hebrajskiego Pierwszej Księgi Machabejskiej z dziełami protokanonicznymi Biblii hebrajskiej. Wiadomo także — choć nie odbywa się to bez trudności — że Septuaginta posiada natchnienie niezależne od swego hebrajskiego pierwowzoru zwłaszcza tam, gdzie jej wersety różnią się od tekstów hebrajskich, gdy można mówić o natchnieniu własnym czy bezpośrednim hagiografów. Lecz dzieje się analogicznie również tam, gdzie tłumaczenie jest wierne oryginałowi i wówczas nie należy mówić o natchnieniu pośrednim czy wtórnym, lecz pierwotnym i niezależnym autora greckiego ze względu na kompozycję własną jego dzieła, słownictwo, którego używa, i idee, które zamierzał zawrzeć w tym, co po sobie pozostawił. Ostatecznie między hebrajskim oryginałem a wersją grecką upływa kilka dobrych wieków rozwoju wiary Izraela i nośność teologiczna danego teks-

${ }^{3}$ Temat ów omówiony został szczegółowo w: J. Nawrot, Pierwsza Księga Machabejska, rozdziały 1,1-6,16, Wstęp - przektad z oryginatu - komentarz, NKB.ST, t. XIV, cz. I, Częstochowa 2016, s. 184-190. 
tu, tłumaczona przez autora późniejszego, jest najprawdopodobniej inna (choć absolutnie nie przeciwna!), z pewnością bogatsza niż tego, spod którego ręki wyszedł tekst pierwotny ${ }^{4}$.

Idąc tym śladem, zauważyć trzeba własną linię teologiczną autorów Septuaginty w każdym z omawianych wersetów podstawowych, gdy pojawiający się stały, hebrajski zwrot lô'-tikrōt (...) berît oddany został przez ou synkatathēse (...) diathēkē $\mathrm{w} \mathrm{Wj} 23,32$, mēpote thēs diathēkēn $\mathrm{w} \mathrm{Wj} 34,12$, ou diathēsē (...) diathēkēn w Pwt 7,2 oraz tak samo, choć w liczbie mnogiej: ou diathēsesthe diathēkēn w Sdz 2,2. Można więc mówić o inwencji własnej autorów greckich, będących pod natchnieniem niezależnym od tych, spod których pióra wyszedł tekst hebrajski. Prawdopodobnie z taką właśnie świadomością odwoływał się do tych tekstów w sposób, jaki przyjdzie wyjaśnić, autor Pierwszej Księgi Machabejskiej.

Liczne teksty mówią o uczynieniu przymierza między Bogiem a Jego ludem, oddawanego najczęściej konstrukcją diatithēmi z diathēkē, która stanie się podstawowym związkiem wyrazowym, badanym w niniejszym tryptyku. Pojawia się on w tekście natchnionym wówczas, gdy strony zawierające pakt są nierówne. Spora natomiast ich liczba wspomina układy czynione między ludźmi, chociaż w Biblii zachodzi to wyłącznie między Izraelitami lub w związku z narodem wybranym a poganami ${ }^{5}$. Oznacza to, że samo połączenie obu terminów nie jest wyłącznie zarezerwowane dla przymierza między Bogiem a Izraelem. Tam, gdzie termin diathēkē użyty zostaje jako grecki odpowiednik $b^{e}$ rît, chodzi zawsze o przymierze lub relację prawną między dwoma partnerami, choć o różnym charakterze.

\section{Fundament teologiczny zapisów prawa}

We wszystkich czterech wersetach głównych pojawia się zakaz zawierania jakichkolwiek paktów z poganami, połączony z koniecznością zniszczenia wszelkich przejawów ich działalności religijnej, ponieważ mogłoby to doprowadzić do niewierności ludu nakazom Bożym.

${ }^{4}$ Por. P. Auvray, Comment se pose le problème de l'inspiration des Septante, RB 59/3 (1952), s. 321-336, tu: s. 333-335.

${ }^{5}$ Por. Rdz 21,32; 26,28; 31,44; Joz 9,6-7.11.15-16; 1 Bas 11,1-2; 22,8; 23,18; 2 Bas 3,1213.21; 5,3; 3 Bas 5,26; 15,19; 21,34; 4 Bas 11,4; 11,17; 1 Par 11,3; 2 Par 16,3; 23,3.16; Oz 12,2; Ez 17,13. Oznaczenia ksiąg pisanych italikiem są następujące: 1 Bas $=1 \mathrm{Sm} ; 2$ Bas $=2 \mathrm{Sm}, 3$ Bas = $1 \mathrm{Krl}, 4 \mathrm{Bas}=2 \mathrm{Krl}, 1 \mathrm{Par}=1 \mathrm{Krn}, 2 \mathrm{Par}=2 \mathrm{Krn}, 2 \mathrm{Ezd}=\mathrm{Ezd}(2 \mathrm{Ezd} 1-10)+\mathrm{Ne}(2 \mathrm{Ezd} 11-20)$, $P S=$ Księga Psalmów z numeracją w Septuagincie, Ier = Księga Jeremiasza z jej podziałem w Septuagincie. 


\section{a) kodeks przymierza}

Werset $\mathrm{Wj}$ 23,32 brzmi następująco:

\section{Nie zaakceptujesz przymierza z nimi ani z ich bogami}

Tekst ów należy do najważniejszej części całej księgi, jaką jest zawarte między Bogiem a Jego ludem przymierze synajskie (Wj 19,1-24,18). W skład tego passusu wchodzi węższy fragment 23,20-336 , z wyimkiem 23,31-33, którego tematem wiodącym są końcowe obietnice wynikające z przymierza oraz ostrzeżenia przed idolatrią ${ }^{7}$. Poprzedzający w. 31 zawiera dwie ważne kwestie: oznaczenie przez Boga granic kraju nadanego ludowi (w. 31a) oraz zapewnienie o pomocy w okresie wypędzania zeń pogańskich narodów (w. 31b). Z kolei następujący w. 33 uzasadnia zakaz wchodzenia w przymierza niebezpieczeństwem odejścia ludu od Boga przez popadnięcie w bałwochwalstwo. Tekst pojawia się jako żądanie warunkujące wejście w przymierze, którego zawarcie ma właśnie nastąpić. Oznacza to wyraźne stwierdzenie wyłączności praw, jakie Bóg nabywa w stosunku do swego ludu. $Z$ drugiej strony tubylcy przeznaczeni są do wytępienia z racji bałwochwalczego, a tym samym niebezpiecznego dla trwałości wiary Izraela stylu życia (w. 27-30). Zawieranie z nimi jakichkolwiek przymierzy sprzeciwiałoby się decyzji Boga o ich eksterminacji i załamałoby wartość przymierza z Nim. Nie dziwi więc tak ostry zakaz wchodzenia z nimi w jakiekolwiek relacje.

Najważniejszy w cytacie czasownik synkatatithēmi (,daję przyzwolenie”) pojawia się w Septuagincie jeszcze tylko raz, w tekście Wj 23,1, w związku z zakazem akceptowania matactw w sądzie. Nie można aprobować postępowania niegodziwca, by nie stanąć po jego stronie jako fałszywy świadek. W obu więc wersetach pojawia się on w kontekście ściśle prawniczym, czyli zobowiązującym strony do odpowiedniego do okoliczności zachowania się względem drugiego człowieka ${ }^{8}$. Zaakcentować trzeba $\mathrm{w}$ tym momencie aprobatę post discussionem, czyli po zyskaniu argumentów na rzecz jednej lub drugiej postawy, a więc postępowanie świadome i przemyślane. Takie zaś nie daje możliwości późniejszego tłumaczenia się z ewentualnych błędów na skutek niedoinformowania. Niewątpliwie fundamentem całości żądania Boga jest stała pamięć wpierw o Jego dobrodziejstwach, których Izrael stał się świadkiem, jak i przyznanie Mu prawa do su-

${ }^{6}$ Taką całość widzi m.in. J. Lemański, Księga Wyjścia..., s. 505.

${ }^{7} \mathrm{~W}$ ten sposób m.in. D.K. Stuart, Exodus. An Exegetical and Theological Exposition of Holy Scripture, NAC 2, Nashville 2006, s. 549.

${ }^{8}$ Ten sam kontekst udzielenia zgody na konkretne działania podczas negocjacji, narad lub spotkań stron jest widoczny w literaturze klasycznej, por. Demostenes, De corona 166; Diodor Sycylijski, Bibliotheca 9,26.5; 12,63.2; 13,12.3; 14,55.7; 15,66.1; 17,28.4; Polibiusz, Historiae $1,49.4 ; 2,48.6 ; 3,98.11 ; 18,43.11$ itd. 
werennych decyzji względem ludu, który nabył jako swą własność, „wykupując” go z niewoli egipskiej (Wj 19,4-6).

\section{b) mowa Boga podczas odnowienia przymierza}

Wj 34,12a:

Uważaj na siebie, abyś nie ustanawiat przymierza

z mieszkańcami ziemi, do której wkraczasz

Niewielka sekcja w. 12-16 omawia ostrzeżenia wobec możliwości zawierania paktów z dotychczasowymi mieszkańcami ziemi obiecanej w formie klauzuli (w. 12), nakazu zburzenia wszelkich oznak bałwochwalstwa (w. 13), zakazu oddawania im czci (w. 14), zakazu uczestnictwa w zgromadzeniach ofiarnych na cześć bóstw (w. 15) oraz zawierania małżeństwa z poganami (w. 16)9. Także w tym wypadku zakaz fundowany jest na uprzedniej woli Boga, który decyduje się wypędzić przed Izraelitami dotychczasowych mieszkańców kraju (w. 11), a więc zawieranie $\mathrm{z}$ nimi przymierzy ${ }^{10}$ byłoby zanegowaniem Jego postanowień radykalnego usunięcia niebezpieczeństwa synkretyzmu religijnego, do którego niewątpliwie doszłoby, gdyby Izraelici wystąpili przeciw woli Bożej. Sami mieszkańcy mogliby stać się wówczas sidłem dla słabych religijnie członków narodu wybranego ${ }^{11}$. Po raz drugi zakaz ów pojawia się w w. 15, należącym do tego samego kontekstu w. 12-16, choć tu chodzi ściśle o niebezpieczeństwo udziału w zakazanym kulcie idolatrycznym, do którego poganie mogliby zachęcić Izraelitów przez proponowanie spożywania ofiar składanych swym bożkom. Czyniąc tak, Bóg pragnie uświęcić swój lud, czyli odseparować go od reszty innych, by uchronić go od zarażenia się pogaństwem na trzech fundamentalnych poziomach egzystencji: w sferze prawdy przez jej zanegowanie wiarą w inne bóstwa, w sferze moralności przez przyjęcie pogańskiego stylu życia, zwłaszcza rozwiązłości, wreszcie w sferze kultu przez składanie ofiar bożkom lub ich spożywanie ${ }^{12}$.

9 Taka postawa staje się przeciwna nakazowi oficjalnego świętowania wyłącznie ku czci Boga, co zostało explicite wyrażone w zapisie 23,14-19, por. E. Otto, Das nachpriesterschriftliche Pentateuchredaktion im Buch Exodus [w:] M. Vervenne, Studies in the Book of Exodus: Redaction, Reception, Interpretation, BETL 126, Leuven 1996, s. 61-112, tu: s. 93.

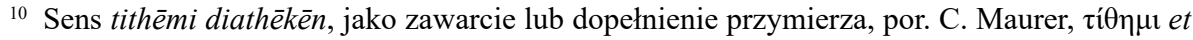
al., tithēmi, TDNT VIII, s. 152-168, tu: s. 154.

${ }^{11}$ Por. H. Ausloos, Deuteronomi(sti)c Elements in Ex 23,20-33? Some Methodological Remarks [w:] M. Vervenne, Studies in the Book of Exodus: Redaction, Reception, Interpretation, BETL 126, Leuven 1996, s. 481-500, tu: s. 496.

${ }^{12}$ D. Gibson mówi tu o swoistej „,kwarantannie” Izraelitów w celu zapobieżenia zarazie bałwochwalstwa, por. tenże, First-Century Truth for a Twenty-First Century World, [bmw] 2011, s. 93. 
Podobną do ou synkatathēsē w 23,32 rolę w wersecie 34,12 pełni zwrot proseche seautō, „bacz na siebie samego”, co natychmiast sugeruje konieczność kontroli własnego postępowania, które nie jest ograniczone żadnymi czynnikami przymusu lub utrudnień w spełnieniu życzenia Boga. Poza dwoma wersetami Rdz 24,6 oraz Pwt $24,8^{13}$ we wszystkich pozostałych 14 przypadkach zwrot ów dotyczy postawy nakazującej moralną wierność bezpośrednio nakazom Boga lub ogólnie przyjętym normom etycznym ${ }^{14}$. Istotą wyrażenia jest - jak w tamtym wypadku — wolna decyzja całej społeczności i każdego jej członka uwidoczniona permanentnym staraniem o posłuszeństwo Bożym zaleceniom i czujnością wobec stale zagrażającego niebezpieczeństwa zejścia z drogi wierności. Postawę taką cechuje sens samowychowywania do wierności ${ }^{15}$. Tymczasem do tego, co stanowiło fundament żądania Boga, ukazany w 23,32 dochodzi jeszcze szczegółowe wspomnienie wielkiego grzechu bałwochwalstwa u stóp Synaju (Wj 32,1-9) i związanego z tym prawa do wyniszczenia całości ludu, zastąpionego ostatecznie przebaczeniem Boga na skutek interwencji Mojżesza. Wydaje się w tym kontekście, że nakaz 34,12, potwierdzony w w. 15, jest teraz jeszcze silniej wyartykułowany niż pierwszy, obecny w 23,32. Jednak sam w. 15 znajduje swe dodatkowe uzasadnienie w poprzedzającym go w. 14, w którym widnieje definicja Boga jako theos dzēlōtēs („Bóg zazdrosny”), co stanowi dokładną kalkę hebr. zwrotu 'êl qannā. Jest to symboliczne wyrażenie prawa Boga do wyłączności i pełni oddawanej Mu czci przez Jego lud ${ }^{16}$ połączone z gotowością szybkiej reakcji karnej na wszelkie wykroczenia ${ }^{17}$. Owa „zazdrość” Boga nie odnosi się jedynie do konieczności uszanowania Jego czynów, jakich dokonał dla dobra swego ludu, lecz stanowi część Jego natury, część tego, co oznacza samo Jego imię ${ }^{18}$.

\section{c) wersja Księgi Powtórzonego Prawa}

Cytat Pwt 7,2b brzmi następująco:

nie sprzymierzysz się z nimi przymierzem i nie zlitujecie się nad nimi

${ }^{13} \mathrm{~W}$ pierwszym chodzi o postępowanie sługi Abrahama co do okoliczności znalezienia żony dla Izaaka, w drugim jest mowa o postępowaniu w sprawie choroby trądu.

${ }^{14}$ Por. Wj 10,28; 23,21; Pwt 4,9; 6,12; 8,11; 11,16; 12,13.19.30; 15,9; Tb 4,12.14; Syr 29,20.

15 Por. G. Bertram, $\pi \alpha 1 \delta \varepsilon ́ v \omega$, TDOT V, s. 596-625, tu: s. 614.

${ }^{16}$ Por. J.F. MacArthur, The MacArthur Bible Commentary, Nashville-Dallas-Mexico CityRio de Janeiro 2005, s. 112.

17 Por. W.H.C. Propp, Exodus 19-40. A New Translation with Introduction and Commentary, AB 2A, New York-London-Toronto-Sydney-Auckland 2006, tu: s. 171.

18 Por. J. Goldingay, Old Testament Theology, vol 1: Israel's Gospel, Downers Grove 2003, s. $422-423$. 
Szeroki kontekst w. 1-26 omawia relację narodu wybranego z tubylcami, których należy wydziedziczyć z ziemi, którą lud idzie posiąść. Węższy kontekst w. 1-11 zapoczątkowuje całą kwestię w formie konkretnych nakazów, dzieląc je na kilka podstawowych jednostek. Passus w. 1-5 zakazuje wchodzenia $\mathrm{w}$ jakiekolwiek relacje $\mathrm{z}$ poganami zamieszkującymi ziemię obiecaną. Wersety 6-11 ukazują specjalną relację Boga do swego ludu, domagającą się drakońskich posunięć ze strony ludu, jeśli chce on okazać Bogu wierność, przy czym w. 11 wzywa do całkowitej wierności wszystkim zaleceniom i nakazom Bożym jako odpowiedź na ów szczególny związek Boga ze swym ludem. Jedna z koncepcji podziału tekstu biblijnego na szczegółowe jednostki tekstowe zalicza w. 2 do najbliższego kontekstu w. 1-3, stawiając akcent na jedność tematyczną: konieczność wyrzucenia pogan z ziemi danej przez Boga Izraela ${ }^{19}$. Inni egzegeci oddzielają w. 1 od następującego po nim fragmentu w. 2-4 ze względu na styl wypowiedzi. Werset 1 jest bowiem oznajmieniem przyszłego dzieła Bożego, podczas gdy w. 2-4 stanowią nakaz konkretnego postępowania ludu wobec pogan ${ }^{20}$.

Werset 2 wyraźnie dzieli się na dwie części połączone wspólną formą trybu rozkazującego, z których pierwsza zawiera trzy segmenty: oznajmienie przez Boga zwycięstwa w przyszłej walce $\mathrm{z}$ tubylcami, nakaz ich wytępienia i obłożenia klątwą (w. 2a). W części drugiej pojawiają się z kolei dwa punkty: zakaz zawierania przymierzy z nimi oraz nakaz bezlitosnego ich potraktowania (w. $2 b$ ). Całość tekstu ukazuje radykalizm postępowania Izraelitów wobec pogan i konsekwentne ich wyrugowanie z przestrzeni życia ludu. Z punktu widzenia treści artykułu najważniejsze jest tu połączenie czasownika diatithēmi (dosł. „,dysponować, dystrybuować, rozdzielać”) z diathēke (,przymierze”), co w tym konkretnym połączeniu daje sens propozycji zawarcia paktu między stronami ${ }^{21}$. Uzasadnieniem zakazu Pwt jest możliwość odwiedzenia Izraelitów od prawdziwej wiary i zachęta do bałwochwalstwa, co spowodowałoby gniew Pana i ich wytracenie (w. 4). Poganie są bowiem postrzegani jako bezbożni przestępcy, niezdolni do nawrócenia się na wiarę w Boga Izraela, podpadający pod klątwę hẹerem, czyli nakaz całkowitej eliminacji wszystkich oraz zniszczenia ich dobytku ${ }^{22}$.

${ }_{19}$ W ten sposób m.in. D.L. Christensen, Deuteronomy 1:1-21:9, WBC 6A, Dallas 2001, s. 155.

${ }^{20}$ Tutaj m.in. D.K. Stuart, Exodus..., s. 177-180.

${ }^{21}$ W sensie „osiągnięcia porozumienia” lub „ustanowienia porządku” wynikającego z podjęcia

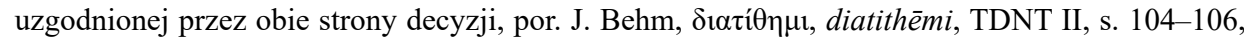
tu: s. 105. Połączenie diatithēmi z diathēkē pojawia się także w literaturze antycznej w sensie wyrażenia decyzji uczynienia konkretnego aktu własnej woli, por. Izajos, Cleonymus 1,15.48; Demostenes, Contra Stephanum II 46,15; Platon, Leges 11,922c; por. także Barnabae Epistula 14,7.

${ }_{22}$ Por. E.H. Merrill, Deuteronomy. An Exegetical and Theological Exposition of Holy Scripture, NAC 5, Nashville 1994, s. 179. 
Podobną myśl prezentuje ostatecznie również werset $\mathrm{Sdz}$ 2,2, zawierając to samo połączenie diatithēmi $\mathrm{z}$ diathēke, przypominając jedynie mowę Boga z Pwt 7,2-5.

We wszystkich przytoczonych wyżej tekstach kluczowe znaczenie dla poprawnego ich zrozumienia niesie rzeczownik diathēkē, jako stały odpowiednik hebrajskiego rzeczownika $b^{e} r \hat{t}$, początkowo oznaczającego konkretny akt prawny, nie zaś stan, jaki z niego wynika. Chodziło zatem o ściśle wyartykułowaną regulację prawną, na mocy której zostało powzięte uroczyste zobowiązanie, wiążące obie strony, dające sobie wzajemne obietnice, w które się angażują ${ }^{23}$. Diathēkē, jako ekwiwalent $b^{e} r i t$, pojawia się w Biblii bardzo często ${ }^{24}$, lecz w cytowanych księgach występuje wyłącznie w ścisłym związku z Bogiem, będącym stroną przymierza. Wyjątek stanowią omawiane cztery powyższe wersety ksiąg, gdzie termin ów zastosowany został do zakazu sprzymierzania się z mieszkańcami kraju, do którego zdąża lud Pana. Zatem sens zakazu wybrzmiewa jasno i bez możliwości błędnej interpretacji: Izraelitom nie wolno zawierać przymierzy z pogańskimi mieszkańcami kraju, do którego się udają, zarówno co do treści, jak i sposobu, w jaki zawarli je ze swym Bogiem. Taki sens thumaczy również zakaz zawierania przymierzy z ,ich bogami”, gdyż byłyby one traktowane na równi z jedynym, prawdziwym Bogiem Izraela, co dawałoby legitymizację ich istnienia i jakiegokolwiek wpływu na życie narodu wybranego. One po prostu nie istnieją, dlatego nie może być żadnego przymierza z fałszywymi bożkami. Wyraża się w ten sposób absolutna wyłączność związku narodu wybranego ze swoim Bogiem, którego żadne inne praktyki nie mają prawa naruszać ani zastępować $^{25}$. Taka interpretacja uzasadnia również to, że na relację między Bogiem a Jego ludem nie został w Septuagincie użyty żaden inny termin prawny, znany w słownictwie greckim ${ }^{26}$. Chociaż bardzo często diathēkē w relacji Bóg-lud nie oznacza przymierza, lecz zwykłe zalecenia czy rozporządzenia ${ }^{27}$, we wszystkich powyższych cytatach głównych chodzi niewątpliwie o przymierze w sensie ścisłym, przeciwstawione takiemu samemu rozumieniu przymierza ludu z Bogiem

${ }^{23}$ Por. C. Westermann, La théologie de l'Ancien Testament, Genève 1985, s. 50-51.

${ }^{24}$ Por. Wj 2,24; 6,4-5; 19,5; 23,22; 24,7.8; 27,21; 31,7.16; 34,10.12.15.27-28; 39,14 oraz Pwt $4,13.23 .31 ; 5,2-3 ; 7,9.12 ; 8,18 ; 9,5.9 .11 ; 10,8 ; 17,2 ; 28,69 ; 29,8.11 .13 .19-20.24 ; 31,9.16 .20 .25-$ $26 ; 33,9$.

${ }_{25}$ Por. D.E. Gowan, Theology in Exodus: Biblical Theology in the Form of a Commentary, Louisville 1994, s. 175.

${ }^{26} \mathrm{~Np}$. nomos, prostagma, entole, dikaiōma, krima, a także czasowniki związane z tymi terminami: entelomai, fylassō, tērē̄, parabainō, parerchomai, emmeneō, poreuomai, por. J. Behm, $\delta 1 \alpha \theta \eta \dot{\kappa} \eta$, diathēke, TDNT II, s. 126-127.

${ }^{27}$ Por. np. Rdz 6,18; 15,18; 17,2-3; Wj 2,24; 6,4; 31,16; Kpł 24,8; 26,9; Pwt 4,23.31; 8,18 itd. 
na fundamencie $\mathrm{Wj}$ 24,1-8 oraz 34,10. Chodzi więc o akt trwały, niezmienialny, którego konsekwencje będą obowiązywały w całej historii ludu.

Co jednak jest równie ważne we wszystkich tych wersetach — zakaz dotyczy ściśle paktowania z narodami najbliższymi Izraelitom w ziemi obiecanej. Cytat Wj 23,31, poprzedzający główny w. 32, wspomina o mieszkańcach kraju, jaki Bóg odda we władanie swemu ludowi, nie wymieniając ich $\mathrm{z}$ nazwy. $\mathrm{Z}$ kolei tekst Wj 34,11 wymienia już explicite sześć nacji zamieszkujących obszar przyrzeczony Izraelitom, podobnie do Pwt 7,1, dorzucającego jeszcze Girgaszytów, nieobecnych $\mathrm{w}$ wersecie poprzednim. Wszystkie te narodowości — znów bez Girgaszytów - wymienione zostały w pierwszym tego typu cytacie Wj 3,8, jako zamieszkujące ziemię, stanowiącą cel wędrówki ludu z Egiptu. Wersety zdają się przemawiać za restrykcyjnym pojmowaniem zakazu, czyli ograniczeniem go jedynie do narodów sąsiadujących bezpośrednio z Izraelem, zajmujących terytorium, które mają zająć członkowie narodu wybranego. Nigdzie zaś teksty prawnicze Pięcioksięgu nie wspominają narodów dalekich. Odpowiedzi na kolejne, postawione we wstępie pytania, spróbują udzielić następne punkty niniejszego rozważania.

\section{Przymierze z Gabaonitami}

Passus Joz 9,3-27 opowiada o pakcie zawartym między Izraelitami a Gabaonitami jako skutek oszustwa tych drugich, lecz również błędu ze strony Izraelitów, którzy uwierzyli kłamcom, nie pytając Boga o zdanie w tej kwestii. Całość składa się z trzech dużych jednostek tekstowych:

a) podstęp Gabaonitów (w. 3-15);

b) zdemaskowanie podstępu (w. 16-21);

c) decyzja Jozuego wobec oszustów (w. 22-27) ${ }^{28}$.

Najważniejsze z punktu prezentowanego artykułu są w. 3-15, na które składają się: wstęp do działań Gabaonitów (w. 3-4a), opis podstępu (w. 4b-6a), dialog z Izraelitami (w. 6b-13), potwierdzenie mowy wysłanników gabaonickich przez Izraelitów (w. 14), zawarcie przymierza (w. 15). Główne wypowiedzi, zawierające najważniejszy termin diathēke, umieszczone zostały w następujących wersetach: $6,7,11$ oraz $15^{29}$.

\footnotetext{
${ }^{28}$ Por. S. Wypych, Księga Jozuego, NKB.ST 6, Częstochowa 2015, s. 242.

${ }^{29}$ Werset 15 ma tę samą konstrukcję wyrazową co wersety 6,7 i 11, więc nie zostanie szczegółowo omówiony.
} 
w. 6: z ziemi dalekiej przybyliśmy, więc teraz zawrzyjcie z nami przymierze

Propozycja ustanowienia relacji między oboma społecznościami w myśl wersetu ma się zbudować na fundamencie pochodzenia przybyszów z jakiegoś dalekiego kraju. Nominalnie nie stanowi to zatem przeszkody do zawarcia przymierza, skoro omawiane wcześniej teksty prawnicze zakazują wprost czynienia umów z najbliższymi sąsiadami. W ten sposób hagiograf sugeruje, że zamieszkanie kontrahentów paktu nie w bezpośrednim pobliżu zainteresowanych nie jest sprzeczne z Bożym zakazem. W taki rozszerzający sposób należy rozumieć postulat zawarcia przymierza $\mathrm{w}$ w. 6 . Nie chodzi bowiem jedynie o samych wysłańców, lecz całą wspólnotę, którą reprezentują. Izraelici w ten właśnie sposób zrozumieli również tę prośbę $(9,17-20)^{30}$. Werset zawiera wpierw stwierdzenie faktu przybycia z ziemi dalekiej, co przywołuje ważny tekst Pwt 20,15, nakazujący pozostawienie przy życiu, w razie ewentualnego konfliktu, kobiet i dzieci spośród mieszkańców miast dalekich od Izraela, gdy lud pokona nieprzyjaciół, natomiast wycięcie wszystkich mężczyzn wrogiej społeczności. Według fragmentu Pwt 20,10-11 postawa Izraelitów ma być uzależniona od dobrowolnego przystania tubylców na oferowane przez zwycięzców warunki pokoju ${ }^{31}$. Werset 20,16 nakazu prawa żąda zabicia wszystkich mieszkańców tylko w miastach, narodów wymienionych explicite w prawie Wj 34,11 oraz Pwt 7,1 a ogólniej w Wj 23,31. W tych wypadkach nie może być mowy o jakichkolwiek negocjacjach.

Wzmocnieniem tej świadomości jest specjalne pytanie zadane przez Izraelitów w kolejnym wersecie:

w. 7b: Spójrz! Nie mieszkasz pośród mnie, po cóż miałbym zawrzeć z toba przymierze?

Ten dość trudny w interpretacji werset Septuaginty można zrozumieć w taki sposób, że albo z racji dalekiego zamieszkania przymierze z obcym ludem jest w ogóle niepotrzebne, skoro nie stanowi on zagrożenia dla wiary Izraelitów, albo propozycja Gabaonitów spełni warunki Pwt 20,10-11 w przypadku przyszłej konfrontacji. Pewna naiwność Jozuego, na którą zdaje się zwracać uwagę właśnie autor Septuaginty w powyższym zdaniu, zawiera się już w tym, że daleki kraj tak spiesznie pragnął traktatu i to za wszelką cenę, uznając się nawet za sługi

${ }^{30}$ Por. T.C. Butler, Joshua, WBC 7, Waco 1983, s. 103-104.

31 Zgoda Jozuego na zachowanie przy życiu została złożona wcześniej rodzinie nierządnicy Rahab w zamian za schronienie udzielone wywiadowcom izraelskim (Joz 6,25), co można przyrównać do obecnego kazusu współpracy ze zdobywcami, por. F. Langlamet, Israël et l'habitant du pays, RB 76 (1969), s. 321-350, tu: s. 328. 
Izraelitów, chociaż takiego traktatu z racji swego rzekomego położenia przecież nie potrzebował.

Nieco inaczej przedstawia się sprawa, jeśli tekst rozważyć w oryginale hebrajskim, ponieważ pytanie Izraelitów zawiera w sobie podejrzenie, że przybysze mieszkają blisko, czyli na terenach zajmowanych właśnie przez najeźdźców. Dlatego powinni zostać przeznaczeni do zagłady lub wypędzenia, ponieważ są Chiwwitami (w. 7a) ${ }^{32}$ i w myśl preskrypcji prawa Mojżeszowego podlegają hêrem, czyli klątwie wojennej, której skutkiem ma stać się całkowite wyniszczenie nieprzyjaciół ${ }^{33}$. To właśnie thumaczy zadanie przez Jozuego podwójnego pytania w w. 8 o ich tożsamość i miejsce zamieszkania, po ich wstępnej deklaracji o uznaniu zwierzchnictwa Izraela. Pewną zagadką jest zapis samego hagiografa, że Gabaonici są Chorytami ${ }^{34}$, chociaż oni sami siebie tak nie nazywali. Autor wprowadza $\mathrm{w}$ ten sposób własną ewaluację całego zdarzenia, podkreślając, że stosował się do nich w całości zakaz prawa Mojżeszowego zawierania jakichkolwiek przymierzy ${ }^{35}$.

Wersety 9-10 dają odpowiedź, lecz z pewnością niesatysfakcjonującą pytających, ponieważ nie zostaje wymieniony kraj, o który są pytani posłowie. Pada jedynie stwierdzenie o „kraju dalekim” i pokojowych zamiarach, wspartych wiadomościami o roli Boga Izraela w zwycięstwach odnoszonych przez lud. Mowa o sławie Boga i Jego dokonaniach ${ }^{36}$ na rzecz ludu jest niewątpliwie teologicznym wyrazem captatio benevolentiae słuchaczy dla przedstawianej sprawy ${ }^{37}$. Możliwe jednak także, iż przez swoiste „wyznanie wiary” czynili wrażenie, że są bardziej podatni na wyrzeczenie się własnych bóstw i przejście pod protekcję zarówno zwycięskiego narodu wybranego, jak i jego Boga, gwarantującego pokój i przyszłe awantaże. Taka możliwość tym bardziej mogła skłonić rozmówców izraelskich do coraz większego zaufania ambasadorom rzekomo dalekiego kraju ${ }^{38}$. Tak czy owak cała dotychczasowa prezentacja wysłanników gabaonickich służy

${ }^{32} \mathrm{O}$ ich możliwym pochodzeniu i roli w tekście natchnionym por. H.A. Hoffner, The Hittites and Hurrians [w:] Peoples of Old Testament Times, ed. by D.J. Wiseman, Oxford 1973, s. 221-228.

${ }_{33}$ Suponowane miejsca zamieszkiwania Chiwwitów w ziemi obiecanej por. S. Wypych, Księga Jozuego..., s. 245.

${ }^{34}$ Septuaginta zmienia nazwę mieszkańców Gabaonu na Chorraios (w. 7).

35 Por. D.M. Howard, Jr., Joshua. An Exegetical and Theological Exposition of Holy Scripture, NAC 5, Nashville 1998, s. 225.

${ }^{36}$ Chytrze wymieniają dawniejsze zwycięstwa Izraelitów, pomijając późniejsze: Jerycho i Aj, jakoby nie znając ich, ponieważ nie dotarły one jeszcze do ich dalekiego kraju, por. R.D. Nelson, Joshua. A Commentary, OTL, Louisville 1997, s. 133.

${ }^{37}$ Podobny temat pojawił się także w mowie Rahab w 2,9-10a, zawierającej ten sam motyw bezpośredniego działania Bożego, por. także Pwt 2,25; Iz 66,19, a w odniesieniu do sławy człowieka por. m.in. $1 \mathrm{Krl}$ 10,1; $2 \mathrm{Krn}$ 9,1; Jdt 14,7; 1 Mch 5,63; 8,1.12.

${ }^{38}$ Por. M. Woudstra, The Book of Joshua, NICOT, Grand Rapids 1981, s. 158-159. 
ostatecznie powtórzeniu w dalszej części mowy dwóch motywów, obecnych już w w. 6 oraz 8: uznania zwierzchnictwa oraz propozycji zawarcia przymierza:

\section{w. 11b: jesteśmy twymi stugami a teraz ustanówcie z nami przymierze}

Prośba realizuje przymierze o charakterze poddańczym między dwoma nierównymi stronami, z których słabsza decyduje się służyć i wspomagać, silniejsza zaś zobowiązuje się do zachowania życia i stanu posiadania słabszej, nadając sobie jednak prawo zmuszenia jej do prac na własną korzyść $(9,21)^{39}$.

Jeśli dotychczasowa mowa nie przekonywałaby interlokutorów, to podano obecnie dwa ważne argumenty na rzecz dalekiego położenia kraju: wygląd chleba, jaki zabrali na drogę, (w. 12) oraz popękanych bukłaków na wino i zdartego ubioru (w. 13). Konieczność uczciwego przekonania się o prawdziwości stwierdzeń wysłanników nakazała spróbowanie czegoś z przywiezionych zapasów (w. 14a), lecz hagiograf natychmiast dodaje, że popełniono błąd, nie konsultując całego wydarzenia z Panem (w. 14b) ${ }^{40}$. Brak należnej ostrożności zdecydował ostatecznie, że przymierze zawarto (dietheto pros autous diathēkēn), dodając jeszcze zobowiązanie do pokoju między stronami oraz przysięgę starszyzny, że Izraelici dotrzymają warunków ugody (w. 15). Już jednak po trzech dniach po zawarciu przymierza (diatesthai pros autous diathēkēn) dowiedziano się o oszustwie Gabaonitów oraz zamieszkiwaniu ich w ziemi, którą Izraelici mieli posiąść (w. 16). W ten sposób ukarana została łatwowierność, która później, już po śmierci Jozuego, zaowocowała niemal powszechnym odstąpieniem Izraelitów od stosowania nakazów prawa ${ }^{41}$.

Niezależnie od tego, że najprawdopodobniej nie jest to opowiadanie historyczne, lecz bardziej etiologiczne ${ }^{42}$, widnieje ono na kartach Biblii jako przykład faktycznego, częściowo zawinionego przekroczenia przez Izraelitów, reprezentowanych przez samego Jozuego, zakazów podanych w prawie Mojżeszowym. Ma ono odpowiedzieć na podstawowe pytanie: dlaczego takowe przymierze zawarto, mimo jasnego przesłania Księgi Wyjścia i Powtórzonego Prawa, a nie skończyło

39 Por. E. Kutsch, Verheissung und Gesetz, BZAW 131, Berlin 1973, s. 53.

${ }^{40}$ Co zwykle dokonywało się przez konsultację przeprowadzaną przez najwyższego kapłana za pomocą losów urim i tummim (Lb 27,21), por. M. Majewski, Wyrocznia efodu oraz urim i tummim w Biblii hebrajskiej, SBO 4 (2012), s. 91-107, tu: s. 101-107. Niektórzy egzegeci chyba słusznie zauważają, że ów błąd postępowania mógł mieć swe korzenie w niehierarchicznej organizacji społeczności gabaonickiej. Nie było tam króla, podczas gdy wszystkie przylegające do Izraelitów społeczności były już rządzone przez władców. Inna więc struktura społeczna mogła zaważyć na tym, że Jozue i Izraelici pozwolili się oszukać, por. S. Wypych, Księga Jozuego ..., s. 244.

41 Por. Sdz 1,19.21.27-33.

${ }^{42}$ Argumentacja por. J. Briend, Israël et les Gabaonites [w:] La protohistoire d'Israël, coll. s. la dir. de E.M. Laperrousaz, Paris 1990, s. 120-182, tu: s. 151-155. 
się to karą ze strony zazdrosnego Boga. Natomiast Jozue nie mógł na koniec swego życia otrzymać najwyższej noty za swą wierność od autora księgi, jak to uczynił on wobec Mojżesza, chociaż w myśl 11,19 nie było miasta w Kanaanie, które zawarłoby przymierze z Izraelitami, poza oszukańczymi Gabaonitami. Wypełniono więc zapis prawa Mojżeszowego niemal wiernie.

Na potrzebę niniejszego rozważania należy zwrócić obecnie uwagę na to, że tekst stanowi potwierdzenie tezy, iż zakaz zawierania przymierzy dotyczył wyłącznie narodów pogańskich, których ziemię Izraelici mieli zająć. Przypadek Księgi Jozuego jest przykładem oszustwa Chiwwitów wobec Izraelitów, lecz w. $7 \mathrm{~b}$ ukazuje możliwość zawierania ugody z krajami lub społecznościami niezamieszkującymi terytorium nadane narodowi wybranemu przez Boga. Jest jednak jasne, że nie może ona dotyczyć jakiejkolwiek zgody na oddziaływanie religii pogańskich na wiarę Izraela. Tak ostre zdefiniowanie zakazów podanych przez Mojżesza wynikało niewątpliwie $\mathrm{z}$ doświadczenia historycznego autorów natchnionych, świadków stopniowego, lecz nieuchronnego upadku wierności Bogu i czystości wiary Izraela. Nie jest to jednak tematem obecnego omówienia.

\section{Sformułowania ogólne pozostałych ksiąg biblijnych}

Kilka poniższych tekstów natchnionych ukazuje generalne stwierdzenia o istnieniu układów i wynikających z nich pewnych zobowiązań, lecz nie precyzuje czasu, zakresu ani warunków ich zawiązywania. Najprawdopodobniej chodzi o ogólne i teologiczne spojrzenie retrospektywne na historię narodu wybranego lub świata pogańskiego, znaczoną być może w którymś ze swoich momentów takimi umowami. Wszystkie poniższe cytaty mają wspólny mianownik inicjatywy ze strony członków narodu wybranego, z tą może różnicą, że pierwszy z nich wspomina o relacjach narzuconych siłą w wyniku wcześniejszych podbojów militarnych, podczas gdy dwa pozostałe mówią o dobrowolnym akcie przystąpienia Żydów do formacji militarnych lub społecznych, stanowiących część stylu życia prowadzonego przez pogan.

\section{a) wyrocznia Amosa przeciw Tyrowi}

Werset Am 1,9 w ten oto sposób zawiera informację na omawiany temat:

Tak mówi Pan:

z powodu trzech niegodziwości Tyru i z powodu czterech nie odwróce jej, ponieważ schwytanych u Salomona uprowadzili do Idumei i zupetnie nie wspomnieli o przymierzu braterskim. 
Oto trzecia z serii ośmiu wyroczni proroka przeciw pogańskim sąsiadom Izraela (w. 9-10) dotyczy Tyru, jedynego miasta wspomnianego osobno w niegodziwości swego postępowania na równi z grzechami ludów otaczających naród wybrany. O tym że nie jest to wyrocznia fikcyjna, świadczy historyczna pewność, iż to bogate wyspiarskie miasto było w VIII wieku przed Chr. jednym z centrów handlu niewolnikami z racji swej dalekosiężnej floty, która zwoziła ich z różnych regionów Morza Śródziemnego. Proceder ów trwał kilka wieków, dzięki czemu miasto ogromnie się wzbogaciło, o czym świadczą zarówno wyrocznie Ezechiela (26-28, zwł. 27,13) jak i — znacznie później - Joela $(3,6)$. Z kolei Edomici mogli służyć jako pośrednicy w rozprowadzaniu schwytanych mieszkańców różnych miast Izraela po regionie Bliskiego Wschodu, chociaż nie jest to pewne ${ }^{43}$. Zagadkowy zwrot ouk emnēsthēsan diathēkēn adelfōn („nie pamiętali o przymierzu braci”) jest dosłowną kalką hebr. konstrukcji o tym samym sensie, przy czym czasownik mimnēskomai oznacza to samo, co hebr. zākar („pamiętać”, tu w sensie „honorować, przestrzegać") ${ }^{44}$. Dlatego zrozumienia zwrotu trzeba szukać w historii Izraela, w czasach funkcjonowania relacji najprawdopodobniej poddaństwa między Izraelem a Fenicjanami, co nastąpiło na skutek zwycięskich wojen wpierw Dawida (2 Sm 5,11), potem Salomona (1 Krl 5,1.11), następnie

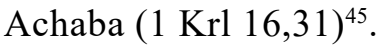

Trudniejszy problem pojawia się $\mathrm{w}$ interpretacji przydawki adelfōn („,braci”), w kontekście najazdów Dawida na sąsiednie państwa i podporządkowywania ich królowi Izraela. Całego zwrotu diathēkēn adelfōn nie ma nigdzie indziej w tekstach natchnionych, dlatego najprawdopodobniej trzeba sięgnąć tu już nie do sfery polityki ${ }^{46}$, lecz całościowej teologii Izraela jako nośnika prawdy o Bogu jedynym i prawdziwym. Ponieważ właśnie Izrael jest z jednej strony dziedzictwem Pana, $z$ drugiej zaś zobowiązany jest rozgłaszać Jego imię pośród narodów, te, które weszły pod jego dominację mogą odnieść jedynie korzyści z tego stanu rzeczy, ponieważ mają możliwość poznać prawdę o Bogu i w ten sposób dołączyć do przymierza, w jakie naród wybrany wszedł z łaski

${ }^{43}$ Por. D. Stuart, Hosea - Jonah, WBC 31, Dallas 1987, s. 312-313. Egzegeci są zdania, że nie chodzi o Edomitów, lecz Aramejczyków, co byłoby prawdopodobniejsze z racji bliskości geograficznej obu regionów i zbytniego oddalenia Edomu od Tyru, por. S. Amsler, Amos [w:] E. Jacob, S. Amsler, C.A. Keller, Osée, Joël, Abdias, Jonas, Amos, CAT XIa, Genève 1982, s. 159-247, tu: s. 174. Podobnie imię Salomona pojawia się w Septuagincie jako błędne odczytanie hebr. przymiotnika še lēmâ (,cały, pełen, kompletny”).

${ }^{44}$ Podobnie do np. Wj 2,24; 6,5; Kpł 26,42.45.

45 Spojrzenie całościowe na problem, por. J. Nawrot, Zagłada Asyrii w teofanicznej symbolice ognia: Analiza tekstu Iz 30, 27-33, Poznań 2000, s. 109-111.

${ }^{46}$ Za tą opcją jednak B.K. Smith, F.S. Page, Amos, Obadiah, Jonah. An Exegetical and Theological Exposition of Holy Scripture, NAC 19B, Nashville 1995, s. 53. 
swego Boga. Innymi słowy: stają się beneficjentami dóbr, jakie Bóg przewidział dla swego ludu ${ }^{47}$. Jest to podstawową treścią całej idei uniwersalistycznej Starego Testamentu ${ }^{48}$.

\section{b) wyrocznia Ezechiela przeciw poganom i Judejczykom}

Omówię z kolei werset Ez 30,5, który relacjonuje smutny koniec ludów pogańskich:

Persowie, Kreteńczycy, Lidowie i Libijczycy

oraz wszyscy mieszańcy, z synów mojego przymierza

padna w niej od miecza.

Treść w. 1-9 wyznacza kontekst bliższy zapowiedzi prorockiej, skierowanej przeciw Egiptowi, przy czym w. 1-5 zwiastują nadejście dnia Pańskiego na ten kraj, w. 6-9 zaś przedstawiają jego tragiczne dla sprzymierzeńców Egiptu skutki. Po formule prorockiej wprowadzającej w wyrocznię (w. 1) oraz słowie wstępnym, wypowiedzianym bez wskazania konkretnego adresata (w. 2a) następuje okrzyk złowrogiego dla Egiptu przekazu (2b) i zapowiedź bliskiej katastrofy dnia Pańskiego wpierw ogólnie wobec narodów (w. 3), potem ściśle wobec Egiptu (w. 4). Od tego ciosu zginą także dotychczasowi sprzymierzeńcy mocarstwa znad Nilu (w. 5) ${ }^{49}$. Narody sojusznicze są częściowo łatwe do identyfikacji jako Nubia, na południe od Egiptu, czyli Etiopia mylnie odczytana w Septuagincie jako Persja, następnie Libia, sąsiad zachodni, oraz Lidia w Azji Mniejszej, które historycznie zawiązały alianse z krajem faraonów. Trudne w interpretacji stwierdzenie pantes hoi empiktoi odnosić może do pochodzenia żołnierzy najemnych poszczególnych armii z rozlicznych krajów ${ }^{50}$.

Najtrudniejszy jednak problem powstaje przy interpretacji zwrotu tōn hyiōn tês diathēkēs mou (,synów mojego przymierza"), stanowiący parafrazę hebr.

${ }^{47}$ W Nowym Testamencie myśl tę najwyraźniej ukazał Paweł w Rz 11,11-32. Por. także M. Bednarz, Powszechność zbawienia w świetle Nowego Testamentu [w:] Uniwersalizm chrześcijaństwa a pluralizm religii: materiały z sympozjum Tarnów-Kraków, 14-15 kwietnia 1999 r., red. S. Budzik, Z. Kijas, Tarnów 2000, s. 31-51.

${ }_{48}$ Por. m.in. Rdz 49,10; 1 Krl 8,43; 2 Krn 6,33; Ps 47,10; Iz 2,2-4; 11,10; 19,19-25; 25,6-8; 45,20-25; 60,4-5; 66,19-20; Mi 4,1-5 Syr 36,17. Znakomite opracowanie tematu por. m.in. S. Szymik, Biblia o powszechności zbawienia, FT 5 (2004), s. 7-21.

${ }^{49}$ Bardziej szczegółowy podział perykopy por. R.M. Hals, Ezekiel, FOTL 19, Grand Rapids 1989, s. 212. Autor widzi jednak początek mowy przeciw nim już w w. 4 a $\beta \gamma b$.

${ }^{50}$ Jako grecki ekwiwalent hebr. kol-hāereb, „cała mieszanka ludów”. Analiza szczegółowa nazw poszczególnych krajów por. A.S. Jasiński, Komentarz do Księgi proroka Ezechiela. Rozdziaty 21-30, OBT 130, Opole 2013, s. 316-317. 
zwrotu bene 'ereș habb rît 'ittām (dosł. „synów kraju przymierza ich") ${ }^{51}$. Od razu widać, że tłumacz grecki nie potrafił zdefiniować sensu pierwowzoru lub - co bardziej prawdopodobne - przypisał mu nową interpretację teologiczną. W Septuagincie zwrot ów występuje wyłącznie w omawianym wersecie, lecz wszędzie tam, gdzie tekst zawiera połączenie diathēkē mou, zaimek odnosi się do Boga Izraela $^{52}$. Z kolei hyios oraz diathēkē nawiązują zawsze do Izraelitów, zobowiązanych do przestrzegania zasad przymierza $z$ Bogiem ${ }^{53}$. Paradoksalnie najlepsze wyjaśnienie złożoności tej konstrukcji oferuje tekst Dz 3,25, w którym Piotr nazywa swych rodaków hyioi tōn profêtōn kai tēs diathēkēs (,synami proroków i przymierza"). Słuchacze niewątpliwie rozumieli to jako dziedzice wielkiej tradycji przodków swego narodu, związanego przymierzem z Bogiem ${ }^{54}$. Autor tekstu greckiego Ezechiela pragnie więc nawiązać do konieczności bycia wiernym przymierzu z Bogiem narodu, co uniemożliwia nawiązywanie przymierzy z imperiami pogańskimi w celu im służenia. Jest bowiem oczywiste, że niezależnie od wielkości swych zbrojnych kontyngentów Izraelici zawsze stanowili mniejszość $\mathrm{w}$ wielonarodowych siłach militarnych imperium znad Nilu i z tego względu łatwiej było im utracić wiarę w swego Boga i przyjąć religie bałwochwalcze. Wchodzili więc dobrowolnie w niebezpieczeństwo utraty własnej wiary ${ }^{55}$. $\mathrm{Z}$ tej racji, łamiąc przymierze z Bogiem, Żydzi służący w wojsku faraona zostaną tak samo pobici jak ich pogańscy partnerzy ${ }^{56}$.

${ }^{51}$ Prawdopodobnie chodzi znów o najemników w armii egipskiej, pochodzących z różnych krajów, które zawiązały pakty polityczno-militarne z faraonami. Taki sens sugerują Targumy oraz Wulgata: „ludy kraju, z którym nawiązali przymierze”, jednak ze szczególnym wskazaniem na Żydów, których związki z Egiptem były w tym czasie bardzo ożywione, por. D.I. Block, The Book of Ezekiel. Chapters 25-48, NICOT, Grand Rapids-Cambridge 1998, s. 159-160.

${ }^{52}$ Por. Rdz 6,18; 9,9.11.15; 17,2.4.7.9.13-14.19.21; 31,44; Wj 6,4; 19,5; 23,22; Kp1 26,9.11.15.44; Pwt 31,16.20; Sdz 2,1.20; Ps 49,16; 88,29.35; 131,12; Oz 8,1; Za 11,10; Ml 2,4-5; Iz 56,4.6; Jr 11,10; Ier 38,32; 41,18; Ez 16,59-60.62; 17,16.19; 44,7; Hbr 8,9.

${ }_{53}$ Por. Rdz 17,19; Wj 6,5; 23,22; 27,21; 31,16; Kpł 24,8; Lb 18,19; 25,13; Pwt 28,69; 29,20; 31,9; 33,9; Joz 3,17; 4,7; 9,2.7; Sdz 8,33; 1 Bas 7,1; 3 Bas 8,9; 19,14; 2 Par 5,2; 13,5; 21,7; 23,3; 25,4; Jdt 9,13; 1 Mch 2,20; Ps 131,12.

${ }^{54}$ Oba zwroty znane były ówczesnym rabinom na wyrażenie statutu Izraelity w odróżnieniu od pogan, por. D. Marguerat, Les Actes des Apôtres, CAT II, Va, Genève 2007, s. 136, przyp. 47.

55 Por. Pwt 7,16; Joz 23,13; Sdz 2,3; Ps 106,35-36.

56 Por. L.C. Allen, Ezekiel 20-48, WBC 29, Dallas 1990, s. 115. Kłóci się to z tezą o Judejczykach, którzy uciekając przed nawałą Nabuchodonozora do Egiptu, złamali słowo Boże objawione im przez Jeremiasza (2 Krl 25,23-26), co sugeruje L.E. Cooper, Sr., Ezekiel. An Exegetical and Theological Exposition of Holy Scripture, NAC 17, Nashville 1994, s. 278-279. Ci bowiem nigdy nie stali się sprzymierzeńcami militarnymi faraona przynajmniej w takim stopniu, że Ezechiel wymieniałby ich obok wojsk najemnych innych krajów w armii króla Egiptu. 


\section{c) pakt z poganami w czasach machabejskich}

W Pierwszej Księdze Machabejskiej wzmianka o pragnieniu części Żydów zamieszkujących swój kraj pojawia się w 1,11ba:

\section{Pójdźmy i zawrzyjmy przymierze z narodami, które mieszkaja wokoło nas}

Przytoczona część wersetu prezentuje propozycję niegodziwców pragnących związać się paktem z poganami (diathōmetha diathēkēn), by przejąć ich zwyczaje i w ten sposób wprowadzić Żydów w krąg kultury greckiej. Posiada on zatem mocny walor religijny ${ }^{57}$.

Chęć zawarcia przymierza na własną rękę oznacza dobrowolne przyjęcie zwyczajów i warunków dyktowanych przez silniejszą stronę, której zasady życia niegodziwi Żydzi aprobują ${ }^{58}$. Gdy dzieje się to z własnej woli, musi zostać ocenione jako wiele gorsze dla społeczności, ponieważ w narzucanych wcześniej przymierzach musiano godzić się na niekorzystne warunki, lecz akceptowano je w celu uratowania resztek niepodległości. Obecnie sami helleniści pragną przejąć zwyczaje obcych narodów, dobrowolnie odrzucając wartości najcenniejsze w dziedzictwie swego narodu. Teologia diatithēmi diathēkēn zawiera niechlubne wspomnienie przeszłości Izraela i Judy, gdy królowie obu państw szukali na własną rękę sprzymierzeńców ${ }^{59}$. Polityka zdradzieckich adherentów oznacza faktyczne odrzucenie Boga, nieliczenie się z Jego prawem do Jego ludu i zastępowanie Jego opatrzności siłą jedynie ludzką ${ }^{60}$. Helleniści zatem dokonują faktycznego wyboru nowego króla Izraela, którym ma być pogański władca. Oznacza to również poddanie się w pełni zaprowadzanym przez niego zwyczajom ${ }^{61}$.

Okoliczne narody, ku którym pragną zwrócić się helleniści, to wpierw greccy mieszkańcy Palestyny, zaludniający tamtejsze miasta wespół z Żydami albo tworzący greckie kolonie na ziemi izraelskiej ${ }^{62}$. Mogą to być także narody pogań-

${ }^{57}$ Por. J. Nawrot, Kryzys religijny w Judei za Antiocha IV Epifanesa. Teologia historii w 1 Mch 1,1-2,26, Studia i Materiały 151, Poznań 2012, s. 67-71.

${ }^{58}$ Por. 1 Bas 11,1-2; 2 Bas 3,21; 4 Bas 16,8-18; 18,14; Ez 17,13.

${ }^{59}$ Por. wspomniane wyżej przykłady, a także Oz 10,4; 12,2 i Józef Flawiusz, Ant. 10, 30-31.

${ }^{60}$ Tak bardzo zawodną i nieprzydatną, nawet jeśli zewnętrznie wygląda ona imponująco, por. J. Blenkinsopp, Isaiah 40-55. A New Translation with Introduction and Commentary, AB 19A, New York 2000, s. 416.

${ }^{61}$ W rzeczywistości równa się to odrzuceniu Boga przez nich samych oraz tych, którzy się z nimi sprzęgną, co doprowadzi ostatecznie do klęski, jak w wypadku działań opisywanych przez Iz 30,1-7, por. J.N. Oswalt, The Book of Isaiah. Chapters 1-39, NICOT, Grand Rapids 1986, s. $544-548$.

${ }^{62}$ Według 2 Mch 4,10 upoważnieni przez Antiocha IV arcykapłani mieli wprowadzać właśnie Hellēnikōn charaktēra, czyli tzw. „obyczaj grecki”, por. W. Fairweather, J. Sutherland Black, The First Book of Maccabees. With Introduction and Notes, Cambridge 1897, s. 59. 
skie otaczające Palestynę, które w owym okresie same mocno się hellenizowały. Wejście z nimi w przymierze oznacza złamanie najbardziej fundamentalnych praw własnego narodu, tzn. tych, dzięki którym do tej pory był on sobą, łatwo identyfikowalny pośród innych wspólnot ludzkich, które wreszcie czyniły go tak wyjątkowym $\mathrm{w}$ świecie pogańskim ${ }^{63}$, a także zamach na fundament religijnej i narodowej tożsamości Izraela. Nikczemność tych działań wynika z postawienia obyczajów obcych narodów wyżej nad własne tradycje i nakazy wynikające $\mathrm{z}$ Tory ${ }^{64}$. W przekonaniu hagiografa zwolennicy wejścia $\mathrm{w}$ bliskie relacje z okolicznymi narodami muszą zostać ukarani, uświadamiając sobie, że owe ludy w myśl Ez 36,4 zakpią sobie z tych, którzy wcześniej uważali ich zwyczaje za lepsze od prawa Bożego. Niewątpliwie postępowanie żydowskich renegatów godzi wprost w zakaz zawiązywania przymierzy z poganami, jaki podany został w prawie Mojżeszowym i to zarówno co do zakresu (pośród kraju Izraela), jak $\mathrm{i}$ istoty (odrzucenie Boga i przyjęcie bałwochwalczych znamion życia osobistego i społecznego).

\section{Podsumowanie}

Próbując ustalić sens zakazu sprzymierzania się z poganami w przytoczonych wyżej tekstach Septuaginty, należy zauważyć następujące prawidłowości:

- zakaz zawierania przymierzy definiuje relację Izraelitów i pogan jako niemożność koegzystencji w sferze religijnej;

- zasadniczym celem zakazu jest uchronienie czystości wiary Izraela przed niebezpieczeństwem popadnięcia w bałwochwalstwo;

- zakaz nie porusza wprawdzie kwestii relacji politycznej lub militarnej między sąsiadującymi społecznościami, zostawia jednak możliwość interpretacji takowych jako potencjalnego zagrożenia dla czystości wiary Izraela;

- zakaz jest limitowany do narodowości zamieszkujących dotychczas ścisły teren wyznaczony na siedziby Izraelitów;

- poza obszarem zamieszkania członków narodu wybranego pod zakaz Mojżeszowy podpadają — choć już indywidualnie — wszyscy, którzy dobrowolnie narażają się na utratę wiary w Boga, angażując się w jakąkolwiek formę służby poganom.

${ }^{63}$ Jak w Pwt 4,6, por. D.L. Christensen, Deuteronomy ..., s. 80.

${ }^{64}$ Odstępcy lekceważą tradycję historyczną supremacji mądrości Izraela nad pogańską, por. m.in. Rdz 40,8; 41,15-16.24; 3 Bas 10,6-7; Dn 1,20; 2,8-10.27-28. 
W świetle powyższych uwag można obecnie przejść do części II niniejszego przedłożenia, w której zostaną omówione pakty i traktaty, jakie zawarli poszczególni bohaterowie biblijni w dziejach Izraela, wspomniane w tekstach natchnionych. Stanie się to tematem kolejnego artykułu.

\section{Israel and its prohibition to ally with Gentiles in selected texts of the Septuagint, part I}

\section{Summary}

This article analyses the problem of Israelites forming an alliance in different times chiefly described in the Pentateuch. Many existing exegetic commentaries lack a clear answer explaining the extent of the prohibition to ally with Gentiles described in Ex 23:32; 34:12; Deut 7:2 and Judg 2:2. The author wants to give a full answer to the question why the prohibition concerns only the nations neighboring Israel after the chosen people started to occupy the Promised Land; or perhaps it also concerns the Gentile nations that neighbored Israel. Should the prohibition be interpreted restrictively or extensively? One should also define the necessity of the prohibition, that is what it actually concerned - any sort of signing a pact with Gentiles or merely the realm of purity of faith so as to dodge the temptation of idolatry. An attempt to answer these questions will broaden the knowledge about these important times of the chosen people.

\section{Keywords}

Old Testament, Septuagint, Pentateuch, alliances, law

\section{Słowa kluczowe}

Stary Testament, Septuaginta, Pięcioksiąg, przymierze, prawo

\section{Zestawienie zastosowanych skrótów}

BZAW - Beihefte zur Zeitschrift für die alttestamentliche Wissenschaft

BETL - Bibliotheca Ephemeridum Theologicarum Lovaniensium

CAT - Commentaire de l'Ancien Testament

FOTL - Forms of the Old Testament Literature

FT - Forum Teologiczne

NAC - New Testament Commentary

NICOT - New International Commentary on the Old Testament

NKB.ST - Nowy Komentarz Biblijny. Stary Testament

OBT _ Opolska Biblioteka Teologiczna

OTL _ Old Testament Library 


$\begin{array}{lll}\text { RB } & - & \text { Revue Biblique } \\ \text { SBO } & - & \text { Scripta Biblica et Orientalia } \\ \text { SKK } & - & \text { Studia Koszalińsko-Kołobrzeskie } \\ \text { TDNT } & - & \text { Theological Dictionary of the New Testament } \\ \text { TDOT } & - & \text { Theological Dictionary of the Old Testament } \\ \text { WBC } & - & \text { Word Biblical Commentary }\end{array}$

\section{Bibliografia}

Allen L.C., Ezekiel 20-48, WBC 29, Dallas 1990.

Amsler S., Amos [w:] E. Jacob, S. Amsler, C.A. Keller, Osée, Joël, Abdias, Jonas, Amos, CAT XIa, Genève 1982, s. 159-247.

Ausloos H., Deuteronomi(sti)c Elements in Ex 23,20-33? Some Methodological Remarks [w:] M. Vervenne, Studies in the Book of Exodus: Redaction, Reception, Interpretation, BETL 126, Leuven 1996, s. 481-500.

Auvray P., Comment se pose le problème de l'inspiration des Septante, RB 59/3 (1952), s. 321-336.

Barnabae Epistula: Barnabas. Kirsopp Lake. The Apostolic Fathers, Vol 1. William Heinemann; The Macmillan Co. London; New York. 1912, http://www.perseus.tufts.edu/hopper/text?doc $=14 \&$ fromdoc $=$ Perseus\%3Atext\%3A2008.01.0629 [dostęp 10.11.2019].

Bednarz M., Powszechność zbawienia w świetle Nowego Testamentu [w:] Uniwersalizm chrześcijaństwa a pluralizm religii: materiały z sympozjum Tarnów-Kraków, 14-15 kwietnia 1999 r, red. S. Budzik, Z. Kijas, Tarnów 2000, s. 31-51.

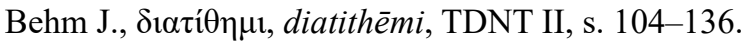

Bertram G., $\pi \alpha 1 \delta \varepsilon ́ v \omega$, TDOT V, s. 596-625.

Blenkinsopp J., Isaiah 40-55. A New Translation with Introduction and Commentary, AB 19A, New York 2000.

Block D.I., The Book of Ezekiel. Chapters 25-48, NICOT, Grand Rapids-Cambridge 1998.

Briend J., Israël et les Gabaonites [w:] La protohistoire d'Israël, coll. s. la dir. de E.M. Laperrousaz, Paris 1990, s. 120-182.

Butler T.C., Joshua, WBC 7, Waco 1983.

Christensen D.L., Deuteronomy 1:1-21:9, WBC 6A, Dallas 2001.

Cooper L.E., Sr., Ezekiel. An Exegetical and Theological Exposition of Holy Scripture, NAC 17, Nashville 1994.

Demostenes, Contra Stephanum II: Demosthenes. Demosthenis.Orationes. ed. W. Rennie. Oxonii.e Typographeo Clarendoniano. 1931, http://www.perseus.tufts.edu/hopper/text?doc $=$ Dem $.+46+15 \&$ fromdoc $=$ Perseus $\% 3$ Atext\%3A1999.01.0077 [dostęp 10.11.2019]. 
Demostenes, De corona: Demosthenes. Demosthenis.Orationes. ed. S.H. Butcher. Oxonii.e Typographeo Clarendoniano. 1903, http://www.perseus.tufts.edu/hopper/te $\mathrm{xt}$ ?doc $=$ Perseus\%3Atext\%3A1999.01.0071\%3Aspeech\%3D18\%3Asection\%3D166 [dostęp 10.11.2019].

Diodor Sycylijski, Bibliotheca: Diodorus Siculus. Diodorus of Sicily in Twelve Volumes with an English Translation by C.H. Oldfather. Vol. 4-8. Cambridge, Mass.: Harvard University Press; London: William Heinemann, Ltd. 1989, http://www.perseus.tufts. edu/hopper/text?doc=Diod.+9.26.5\&fromdoc $=$ Perseus\%3Atext\%3A1999.01.0083 [dostęp 10.11.2019].

Fairweather W., Sutherland Black J., The First Book of Maccabees. With Introduction and Notes, Cambridge 1897.

Gibson D., First-Century Truth for a Twenty-First Century World, [bmw] 2011.

Goldingay J., Old Testament Theology, vol 1: Israel's Gospel, Downers Grove 2003.

Gowan D.E., Theology in Exodus: Biblical Theology in the Form of a Commentary, Louisville 1994.

Hals R.M., Ezekiel, FOTL 19, Grand Rapids 1989.

Hoffner H.A., The Hittites and Hurrians [w:] Peoples of Old Testament Times, ed. by D.J. Wiseman, Oxford 1973, s. 221-228.

Howard D.M., Jr., Joshua. An Exegetical and Theological Exposition of Holy Scripture, NAC 5, Nashville 1998.

Izajos, Cleonymus: Isaeus. Isaeus with an English translation by Edward Seymour Forster, M.A. Cambridge, MA, Harvard University Press; London, William Heinemann Ltd. 1962, http://www.perseus.tufts.edu/hopper/text?doc=Perseus\%3Atext\%3A1999. 01.0141\%3Aspeech\%3D1\%3Asection\%3D15 [dostęp 10.11.2019].

Jasiński A.S., Komentarz do Księgi proroka Ezechiela. Rozdziały 21-30, OBT 130, Opole 2013.

Józef Flawiusz, Antiquitates Ioudaicae: Flavius Josephus. Flavii Iosephi opera. B. Niese. Berlin. Weidmann. 1892, http://www.perseus.tufts.edu/hopper/text?doc=J.+AJ+10.30 $\&$ fromdoc $=$ Perseus\%3Atext\%3A1999.01.0145 [dostęp 10.11.2019].

Kułaczkowski J., Specyfika wybranych zbiorów prawa w Pięcioksięgu, SKK 10 (2005), s. $145-155$.

Kutsch E., Verheissung und Gesetz, BZAW 131, Berlin 1973.

Langlamet F., Israël et l'habitant du pays, RB 76 (1969), s. 321-350.

Lemański J., Księga Wyjścia. Wstęp - przekład z oryginału - komentarz, NKB.ST, t. II, Częstochowa 2009.

MacArthur J.F., The MacArthur Bible Commentary, Nashville-Dallas-Mexico City-Rio de Janeiro 2005.

Majewski M., Wyrocznia efodu oraz urim i tummim w Biblii hebrajskiej, SBO 4 (2012), s. 91-107.

Małecki Z., Izrael i Kościół świętym ludem Jahwe [w:] Vobis Episcopus Vobiscum Christianus. Księga Jubileuszowa dedykowana Księdzu Arcybiskupowi Damianowi Zimo- 
niowi $w$ dwudziestolecie postugi biskupiej $w$ archidiecezji katowickiej oraz $w$ siedemdziesiata rocznicę urodzin, red. W. Myszor, A. Malina, Katowice 2004, s. 218-230.

Marguerat D., Les Actes des Apôtres, CAT II, Va, Genève 2007.

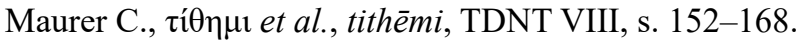

Merrill E.H., Deuteronomy. An Exegetical and Theological Exposition of Holy Scripture, NAC 5, Nashville 1994.

Nawrot J., Kryzys religijny w Judei za Antiocha IV Epifanesa. Teologia historii w 1 Mch 1,1-2,26, Studia i Materiały 151, Poznań 2012.

Nawrot J., Pierwsza Księga Machabejska, rozdziaty 1, 1-6,16. Wstęp - przektad z oryginatu - komentarz, NKB.ST, t. XIV, cz. I, Częstochowa 2016.

Nawrot J, Zagłada Asyrii w teofanicznej symbolice ognia: Analiza tekstu Iz 30,27-33, Poznań 2000.

Nelson R.D., Joshua. A Commentary, OTL, Louisville 1997.

Oswalt J.N., The Book of Isaiah. Chapters 1-39, NICOT, Grand Rapids 1986.

Otto E., Das nachpriesterschriftliche Pentateuchredaktion im Buch Exodus [w:] M. Vervenne, Studies in the Book of Exodus: Redaction, Reception, Interpretation, BETL 126, Leuven 1996, s. 61-112.

Platon, Leges: Plato. Platonis Opera, ed. John Burnet. Oxford University Press. 1903, http://www.perseus.tufts.edu/hopper/text?doc $=$ Plat. + Laws+11.922\&fromdoc=Perseu s\%3Atext\%3A1999.01.0165 [dostęp 10.11.2019].

Polibiusz, Historiae: Historiae. Polybius. Theodorus Büttner-Wobst after L. Dindorf. Leipzig. Teubner. 1893-, http://www.perseus.tufts.edu/hopper/text?doc=Plb.+1.49.4 $\&$ fromdoc=Perseus\%3Atext\%3A1999.01.0233 [dostęp 10.11.2019].

Propp W.H.C., Exodus 19-40. A New Translation with Introduction and Commentary, AB 2A, New York-London-Toronto-Sydney-Auckland 2006.

Smith B.K., Page F.S., Amos, Obadiah, Jonah. An Exegetical and Theological Exposition of Holy Scripture, NAC 19B, Nashville 1995.

Stuart D., Hosea - Jonah, WBC 31, Dallas 1987.

Stuart D.K., Exodus. An Exegetical and Theological Exposition of Holy Scripture, NAC 2, Nashville 2006.

Szymik S., Biblia o powszechności zbawienia, FT 5 (2004), s. 7-21.

Westermann C., La théologie de l'Ancien Testament, Genève 1985.

Woudstra M., The Book of Joshua, NICOT, Grand Rapids 1981.

Wypych S., Księga Jozuego, NKB.ST 6, Częstochowa 2015. 